\title{
Body Fat Percentage and Level of Aerobic Capacity among Students from Upper Primary School 高小學童的體脂肪率和有氧容量水準
}

\author{
K.G. SOH $^{1} \quad$ K. L. SOH ${ }^{2} \quad$ Marjohan Jamalis ${ }^{1}$ \\ Mohd Sofian O. F. ${ }^{1} \quad$ P.Y. LIM ${ }^{1}$ \\ ${ }^{1}$ Sports Studies Department, \\ Faculty of Educational Studies, \\ University Putra Malaysia, MALAYSIA \\ ${ }^{2}$ Department of Community Health, \\ Faculty of Medicine and Health Sciences, \\ University Putra Malaysia, MALAYSIA
1蘇金玉 $\quad 2$ 蘇金蘭 1 莫哈末蘇菲安 ${ }^{1}$ 馬佐漢 ${ }^{1}$ 林保豓
${ }^{1}$ 馬來西亞博特拉大學
教育研究院運動學系
${ }^{2}$ 馬來西亞博特拉大學
醫學和健康科學院社會學系

\begin{abstract}
The rising standard of living in Malaysia has seen changes to its population. Obesity and other diseases of wealth are appearing in younger and younger people, resulting in the need for sports or exercise to stay fit and healthy. Studies have shown an inverse relationship between body fat percentage and aerobic capacity in children (Coleman et al., 2004). However, from the general studies, little is known specifically about Chinese primary school children. Therefore, this research aims to study the body fat and aerobic capacity of Chinese primary school children in Kajang, as possible representative of the national population. It will also ascertain whether there is any gender bias in the relationship. Two hundred and forty students were studied, from Years 4 and 5, equally divided between the sexes. The body fat percentage was determined using the skinfold method on the triceps and calf. After the fat measurement, the subjects were asked to perform the PACER bleep test to assess their aerobic capacity. The boys were found to be significantly superior in aerobic capacity $(\mathrm{t}=1.35, \mathrm{p}<0.18)$ despite having higher body fat. There was a low negative correlation between body fat and aerobic capacity $(r=-0.28, \mathrm{n}=240, \mathrm{p}<0.01)$ among the children which was highly significant because of the large number of samples. In conclusion, $27.50 \%$ of the subjects were founds to have moderately high to very high percentage of body fat confirming the need to exercise to stay fit and healthy among this age group, especially among the boys.
\end{abstract}

Key Words

Body fat, aerobic capacity, children, primary school, Malaysia 


\section{摘 要}

馬來西亞的人口變化提高了人們的生活水準。肥胖和其他富貴疾病都出現于少年和年輕人，導致人們必須多做運動來保持 健壯。Coleman et. al., (2004)的研究證明了兒童的體脂肪率和有氧容量之間的相反關係。然而, 從一般上的研究, 在華小兒童 兩者之間的關係明確少知。所以, 此探索的目的是研究在加影區某間華小兒童的體脂肪和有氧容量, 盡可能作為國家人口的代表 性。借此也探知兩者之間的關係是否有任何性別偏見。研究中共有240位由4、5年級平分的男女學生參與。研究運用測量三肌肉及 腓皮膚表層的方法來固定體脂肪率。測量脂肪後, 受試者需履行往返距離20米的PACER測驗來估算他們的有氧容量。儘管那些男 生擁有較高的體脂肪, 他們卻有卓越顯著的有氧容量 $(\mathrm{t}=1.35, \quad \mathrm{p}<0.18)$ 。因為受試者的人數眾多, 有效的反映出兒童之間的體脂肪 與有氧容量有低陰性關係 $(\mathrm{r}=-0.28, \mathrm{n}=240, \mathrm{p}<0.01)$ 。總結來説, $14.17 \%$ 的受試者擁有高或很高的體脂肪率, 確認了這年齡的兒 童特別是男生必需做運動來保持健壯。

\section{Introduction}

Physical inactivity has led to a rise in hypo-kinetic diseases such as coronary heart disease, hypertension, hypercholesterolemia, cancer, obesity and musculoskeletal disorders (American College of Sports Medicine, 2001; Robaayah, 2004). Modern work which is less physically demanding has led to an increase in obesity (Ismail et al., 2002; Giammattai et al., 2003), and the children of today are much fatter and less fit than those of yesterday (Ismail et al., 2002; Rump et al., 2002). Overweight children will be susceptible to a host of health problems down the line. This is also evidenced in Malaysia, and this unhealthy development is definitely concern the Malaysian health authorities. Our nation now is being weight down by obese Malaysian, with $37 \%$ of the population exceeding their healthy health weight limits (Bahagian Pembangunan Kesihatan Keluarga, 2007). Hence, immediate measures need to be carried out to encourage the Malaysian to be physically active starting form early childhood.

Based on the norm by Lohman (1992), high body fat percentage was classified as having body fat more than $25 \%$ for the boys, and body fat more than $30 \%$ for the girls. This showed that there is an increment in body fat percentage exceeded 25\% for boys and 35\% for girls in Malaysia. Therefore, the main thrusts of this study were to determine the body fat percentage and aerobic capacity $\left(\mathrm{VO}_{2} \max \right)$ of upper Chinese primary school children in Malaysia, and to ascertain the relationship between these two parameters as affected by gender.

\section{Methods and Procedures}

Two hundred and forty upper primary students from a Chinese primary school in Kajang, Selangor, Malaysia volunteered as subjects for the research. They were 10 to 11 years old and evenly divided between the sexes - 120 boys and 120 girls. Their body fat percentage was measured using the skinfold method (Slaughter et al., 1988) on the triceps and calf. The PACER $20 \mathrm{~m}$ bleep test was used to determine their aerobic capacity (Leger et al., 1988). Both tests were chosen because they were reported to be very reliable field test when compared to the laboratory tests. The r-value was 0.89 for the skinfold test and 0.89 for the PACER $20 \mathrm{~m}$ bleep test (Slaughter et al., 1988; Leger et al., 1988).

\section{Statistical Analysis}

Descriptive analysis was used for the percentage body fat and $\mathrm{VO}_{2}$ max. The relationship between the two at $\alpha=0.05$ was established using Pearson's r, based on Guilford's rule of thumb. The t-test was used to determine the significance of differences between the genders for body fat and $\mathrm{VO}_{2} \max$ at $\alpha=0.05$ (Pallant, 2001).

\section{Results}

Table 1 shows the overall results for body fat percentage and $\mathrm{VO}_{2} \max$ for all the subjects. Boys had $19.54 \pm 8.40 \%$ body fat and girls $19.47 \pm 4.34 \%$, only marginally lower. $\mathrm{VO}_{2} \max$ for the boys was $35.19 \pm$ $4.63 \mathrm{ml} / \mathrm{kg} \mathrm{min}^{-1}$ and girls $34.37 \pm 4.75 \mathrm{ml} / \mathrm{kg} \mathrm{min}^{-1}$. Thus, on average, the boys were very slightly fatter and fitter than the girls. The difference in $\mathrm{VO}_{2}$ max between the boys and girls was significant with $t=1.35, p<0.18$. However, the difference in body fat was not so with $t=0.08$, $\mathrm{p}>0.94$. The correlation between body fat and $\mathrm{VO}_{2} \max$ 
was negative and low $(\mathrm{r}=-0.28, \mathrm{n}=240, \mathrm{p}<0.01)$, but highly significant due to the large number of samples.

Based on the body fat norm provided by Lohman (1992), $14.17 \%$ of the subjects were reported to have high body fat percentage (Table 2). On the other hand, based on the fitnessgram in Table 3, 34.58\% of the subjects were reported to be in the "weak" $\mathrm{VO}_{2}$ max category (Cureton \& Plowman, 1999). This research indicated the present of relationship between high body fat percentage and $\mathrm{VO}_{2}$ $\max$ in this age group. The relationship strengthens the need to encourage children to exercise and stay fit and healthy from early childhood.

Table 1. Overall body Fat Percentage and $\mathrm{VO}_{2} \max$ for Boys and Girls.

\begin{tabular}{lllll}
\hline Parameter & Gender & $\mathbf{N}$ & Mean and SD & Overall Mean and SD \\
& Boys & 120 & $19.54 \pm 8.40$ & \\
Fat $(\%)$ & Girls & 120 & $19.47 \pm 4.34$ & $19.51 \pm 6.67$ \\
& Boys & 120 & $35.19 \pm 4.63$ & \\
$\mathrm{VO}_{2} \max \left(\mathrm{ml} / \mathrm{kg} \mathrm{min}{ }^{-1}\right)$ & Girls & 120 & $34.38 \pm 4.75$ & $34.78 \pm 4.70$ \\
\hline
\end{tabular}

\section{Discussion}

Based on the body fat norm provided by Lohman (1992), most of the subjects $(64.58 \%)$ were found to have body fat in the optimal range, $27.50 \%$ were reported to be in the moderately high, high, or very high body fat ranges. And the rest (7.92\%) were reported to be low in body fat. The boys (21.25\%) out-numbered the girls $(6.25 \%)$ in the moderately high to very high body fat groups by more than two-fold although, overall, the boys were only marginally fatter than the girls. This could be due to the girls sprouting in height faster than the boys, and reaching their puberty earlier. Besides that, girls at the age between 10-12 were also reported to be more skeptical about their appearances (Gualdi-Russo et al., (2007). Individually, the boys had more problems with their body fat than the girls. Although the overall means were similar, there were more boys on the fat side - 51 boys had moderately high to very high body fat compared to only 15 girls. And more girls had the optimum fat level $(37.08 \%)$ than the boys $(27.50 \%)$.

Table 2. Numbers and Percentage of Boys and Girls in Different Body Fat Categories based on the Standard by Lohman (1992).

\begin{tabular}{lllllllll}
\hline Body Fat & $($ Boy $)$ & \multicolumn{3}{c}{ Girls } & \multicolumn{3}{c}{ Total Body Fat } \\
\cline { 2 - 8 } Category & Standard & Number & $\%$ & Standard & Number & $\%$ & Number & $\%$ \\
\hline Very High & $>31$ & 13 & 5.41 & $>36$ & 0 & 0 & 13 & 5.42 \\
High & $25.1-31.0$ & 19 & 7.92 & $30.0-36.0$ & 2 & 0.83 & 21 & 8.75 \\
Moderately & $20.1-25.0$ & 19 & 7.92 & $25.1-29.9$ & 13 & 5.42 & 32 & 13.33 \\
High & & & & & & & & \\
Optimal & $9.1-20.0$ & 66 & 27.50 & 15.1 .25 .0 & 89 & 37.08 & 155 & 64.58 \\
Low & $5.2-9.0$ & 3 & 1.25 & $12.1-15.0$ & 16 & 6.67 & 19 & 7.92 \\
Very Low & $\leq 4.7$ & 0 & 0 & $\leq 12$ & 0 & 0 & 0 & 0 \\
\hline
\end{tabular}


The measurement of $\mathrm{VO}_{2} \max$ showed $28.33 \%$ of the boys and $6.25 \%$ of the girls to be 'weak', and $21.67 \%$ of the boys and $43.33 \%$ of the girls were 'good' in tern of $\mathrm{VO}_{2}$ max (Table 3). Only $0.42 \%$ of the girls were in the 'better' group. The boys were generally more active and had higher $\mathrm{VO}_{2}$ max than the girls. Despite the higher overall $\mathrm{VO}_{2}$ max by the boys, only $21.67 \%$ of them were in the 'good' category vs. $43.33 \%$ of the girls. The largest category for the boys was 'weak' $(28.33 \%)$ which had only $6.25 \%$ of the girls. The high number of weak $\mathrm{VO}_{2}$ max boys indicated their physical inactivity - which ties in with the higher body fat reported among them (for moderately high to very high body fat category). Hence, priority should be given to forcing the boys to exercise.

Table 3. Numbers and Percentage of Boys and Girls in Different $\mathrm{VO}_{2}$ max Categories based on the Fitnessgram Criterion Reference Standards by Cooper Institute (Cureton \& Plowman, 1999).

\begin{tabular}{lllllll}
\hline VO & Bax & \multicolumn{3}{c}{ Goys } & \multicolumn{3}{c}{ Gotal VO $_{2}$ max } \\
\cline { 2 - 6 } Category & Number & $\%$ & Number & $\%$ & Number & $\%$ \\
\hline Weak & 68 & 28.33 & 15 & 6.25 & 83 & 34.58 \\
Good & 52 & 21.67 & 104 & 43.33 & 156 & 65.00 \\
Better & 0 & 0.0 & 1 & 0.42 & 1 & 0.42 \\
\hline Total & 120 & 50 & 120 & 50 & 240 & 100 \\
\hline
\end{tabular}

There was only a low correlation between body fat and $\mathrm{VO}_{2} \max (\mathrm{r}=-0.28, \mathrm{n}=240, \mathrm{p}<0.01)$, but made highly significant by the large number of samples. This was also found elsewhere in children and older subjects (Goran et al., 2000). A little fatness and excess body weight do not necessarily imply a reduced ability to consume oxygen, but excess fatness would have a detrimental effect on the aerobic capacity. Thus, fatness and $\mathrm{VO}_{2}$ max should not be considered as independent entities.

\section{Conclusion}

This research found a negative, low relationship between body fat and $\mathrm{VO}_{2}$ max in children from a primary school in Kajang. Individually, the boys were fatter than the girls, and out-numbered them in the overweight groups by more than two-fold. More girls were reported to be in the "good" $\mathrm{VO}_{2} \max$ category as compared to the boys, and had twice as many as the boys in the 'good' category. In conclusion, the Chinese girls were found to have lower body fat and better $\mathrm{VO}_{2}$ $\max$ than the boys (105 girls in the good and better $\mathrm{VO}_{2}$ max category as compared to 52 boys). Moderately high to very high body fat percentage $(27.50 \%)$ was found among the subjects, confirming their need to exercise to stay fit and healthy even at this early age, especially for the boys.

\section{References}

American College of Sports Medicine. (2001). ACSM'S resource manual for guidelines for exercise testing and prescription ( $6^{\text {th }}$ edition). Philadelphia: Lippincott Williams and Wilkins.

Bahagian Pembangunan Kesihatan Keluarga/Family Health Development Division. (2007, Sept 10). Malaysian Ministry of Health. Retrieved from http://fh.moh.gov. my $/$ modules $/$ news $/$ article. php?storyid=32.

Coleman, K. J., Heath, E. M., \& Alcala, I. S. (2004). Overweight and aerobic fitness in children in the United States/Mexico border region. Pan American Journal of Public Health, 15(4), 262-271.

Cureton, K. J., \& Plowman, S. A. (1999). Aerobic capacity assessment-fitnessgram Reference Guide. Dallas: Cooper Institute. 
Giammattai, J., Blix, G., Marshak, H. H., Wollitzer, A. O., \& Pettitt, D. J. (2003). Television watching and soft drink consumption: Associations with obesity in 11 to 13 year old schoolchildren. Archives Pediatrics \& Adolescent Medicine, 157 (9), 882-886.

Goran, M., Fields, D. A., Hunter, G. R., Herd, S. L., \& Weisner, R. L. (2000). Total body fat does not influence maximal aerobic capacity. Int. Journal Obesity, 24,841-848.

Gualdi-Russo, E., Albertini, A., Argnani, L., Celenza, F., Nicolucci, M., \& Toselli, S. (2008). Weight status and body image perception in Italian children. $J$ Hum Nutr Diet, 21, 39-45.

Ismail, M. N., Chee, S. S., Nawawi, H., Yusoff, K., Lim, T. O., \& James, P. T. (2002). Obesity in Malaysia. Obesity Review, 3, 203-208.

Leger, L. A., Mercier, D., Gadoury, C., \& Lambert, J. (1988). The multistage $20 \mathrm{~m}$ shuttle run test for aerobic fitness. Journal of Sports Science, 6, 93-101.

Lohman, T. G. (1992). Advances in body composition assessment. Champaign IL: Human Kinetics.

Pallant, S. (2001). SPSS survival manual : A step by step guide to data analysis using SPSS (version 10). Illinois: Allen and Unwin.

Robaayah, Z. (2004). Trends in cardiovascular diseases and risk factors in Malaysia. Proceeding of the 13th International Atherosclerosis Symposium, V1262: 446-449.

Rump, P., Verstappen, F., Gerver, W. J., \& Hornstra, G. (2002). Body composition and cardiorespiratory fitness indicators in prepubescent boys and girls. International Journal of Sports Medicine, 23, 50-54.

Slaughter, M. H., Lohman, T. G., Boileau, R. A., Horswill, C. A., Stillman, R. J., Van Loan, M. D., \& Bemben, D. A. (1988). Skinfold equations for estimation of body fatness in children and youth. Human Biology; 60, 709-723.

\section{Correspondence:}

Dr. Soh Kim Geok

Sports Studies Department,

Faculty of Educational Studies,

University Putra Malaysia, MALAYSIA.

Tel: $\quad 603-89468153$ (Office) or 6019-3649715 (Mobile)

Fax: $\quad 603-89435386$

E-mail: kim@educ.upm.edu.my or kimgeoks@yahoo.com 